(C) Copyright 2020: Editum. Servicio de Publicaciones de la Universidad de Murcia. Murcia (Spain) ISSN print edition: 0212-9728. ISSN online edition (http://revistas.um.es/analesps): 1695-2294

Online edition License Creative Commons 4.0: BY-SA

\title{
The Young Schema Questionnaire Short Form 3 (YSQ-S3): does the new four-domains model show the best fit?
}

\author{
Matteo Aloi ${ }^{1,3}$, Marianna Rania ${ }^{1,3}$, Raffaella Sacco ${ }^{1}$, Barbara Basile ${ }^{4}$, and Cristina Segura-Garcia ${ }^{2,3^{*}}$ \\ 1 Department of Health Sciences, University Magna Graecia, Catanzaro (Italy). \\ 2 Department of Medical and Surgical Sciences, University Magna Graecia, Catanzaro (Italy). \\ 3 Center for Clinical Research and Treatment of Eating Disorders, University Hospital Mater Domini, Catanzaro (Italy). \\ 4 Association of Cognitive Psychology, School of Cognitive Psychotherapy, Rome (Italy).
}

\begin{abstract}
Título: La versión breve del Young Schema Short Form 3 (YSQ-S3): ¿jel nuevo modelo de cuatro dominios muestra el mejor ajuste?

Resumen: La existencia de esquemas maladaptativos tempranos (EMTs) es el concepto central de Schema Therapy (ST). Varios estudios han demostrado que los EMS están involucrados en muchos trastornos psiquiátricos. El Young Schema Questionnaire es una medida de autoinforme desarrollada para evaluar los 18 EMTs y tiene versiones de forma larga (YSQ-L) y forma corta (YSQ-S). Actualmente se encuentra en su tercera versión (YSQ-S3). Hasta donde tenemos conocimiento, este es el primer estudio que tiene como objetivo validar la versión italiana del YSQ-S3 de acuerdo con la nueva organización propuesta de EMTs en cuatro dominios.

Una muestra no clínica de 1372 estudiantes italianos participó en esta investigación. El análisis factorial confirmatorio (CFA) se realizó para examinar la estructura latente del YSQ-S3, incluidas las estructuras de primer y segundo orden. Se calcularon la omega coeficiente de McDonald y la correlación interclase para evaluar la consistencia interna y la fiabilidad testretest. Las correlaciones entre el YSQ-S3 y la ansiedad y los síntomas del estado de ánimo se calcularon para medir la validez de constructo.

El omega de McDonald de casi todos los EMTs fue superior a 0.7, lo que indicó una buena confiabilidad interna, y la confiabilidad test-retest fue excelente. CFA apoya la nueva organización propuesta de EMS en cuatro dominios. Con respecto a la validez concurrente, cada esquema en el YSQS3 estaba altamente correlacionado con la ansiedad y los síntomas del estado de ánimo.

El nuevo modelo de cuatro dominios del YSQ-S3 ha demostrado que puede ser una herramienta útil y válida para los médicos e investigadores en la medición del autoinforme de los EMTs.

Palabras clave: Schema Therapy; esquema maladaptativo temprano; Young Schema Questionnaire; Validación italiana; Propiedades psicométricas.
\end{abstract}

\section{Introduction}

Schema Therapy (ST) is a recent integrative approach sharing different elements with Cognitive Behavioral Therapy, Gestalt Therapy, Object Relations Theory, Attachment Theory and Transactional Analysis (Young, Klosko, \& Weishaar, 2003).

The concept of early maladaptive schemas (EMS) is the core of ST. Young and colleagues defined EMSs as "extremely stable and enduring themes, comprised of memories, emotions, cognitions, and bodily sensations regarding oneself and one's relationship with others that develop during childhood and are elaborated on throughout the individual's

* Correspondence address [Dirección para correspondencia]: Cristina Segura-García MD, PhD. Department of Health Sciences. University Magna Graecia of Catanzaro.Viale Europa. 88100-Catanzaro (Italy). E-mail: segura@unicz.it

(Articulo recibido: 25-9-2018, revisado: 2-6-2019, aceptado 9-9-2019)
Abstract: The existence of early maladaptive schemas (EMS) is the core concept of Schema Therapy (ST). Several studies have demonstrated that EMSs are involved in many psychiatric disorders. The Young Schema Questionnaire is a self-report measure developed to assess the 18 EMSs and has long form (YSQ-L) and short form (YSQ-S) versions. It is currently in its third version (YSQ-S3). To the best of our knowledge, this is the first study that aims to validate the Italian version of YSQ-S3 according to the new proposed organization of EMSs into four domains.

A non clinical sample of 1372 Italian population was involved in this research. Confirmatory Factor Analysis (CFA) was conducted to examine the latent structure of the YSQ-S3, including both first- and second-order structures. McDonald's omega and intra-class correlation coefficients were calculated to evaluate internal consistency and test-retest reliability. Correlations between the YSQ-S3 and anxiety and mood symptoms were calculated to measure construct validity.

McDonald's omega of almost all EMSs were higher than 0.7, which indicated good internal reliability, and test-retest reliability was excellent. CFA supports the new proposed organization of EMSs into four domains. Regarding concurrent validity, each schema in the YSQ-S3 was highly correlated with anxiety and mood symptoms.

The new four-domains model of the YSQ-S3 has demonstrated that it can be a useful and valid tool for clinicians and researchers in the self-report measurement of EMSs.

Keywords: Schema Therapy; early maladaptive schema; Young Schema Questionnaire; Italian validation; psychometric properties. lifetime, and that are dysfunctional to a significant degree" (Young et al. 2003). According to the ST model, psychiatric disorders result from the development, in childhood, of EMSs in response to unmet emotional needs. In recent years, many studies have shown that EMSs are involved in many psychiatric diseases such as personality disorders (Sempértegui, Karreman, Arntz, \& Bekker, 2013), affective disorders (Davoodi et al., 2018; Hawke, Provencher, \& Arntz, 2011), obsessive-compulsive disorder (Basile, Tenore, Luppino, Mancini, \& Basile, 2017; Voderholzer et al., 2014), social phobia (Calvete et al. 2013; Pinto-Gouveia et al. 2006), eating disorders (Pugh, 2015), substance abuse (Shorey, Anderson, \& Stuart, 2013), and psychosis (Stowkowy et al., 2016).

The Young Schema Questionnaire (YSQ; Young \& Brown, 1990) is a self-report measure developed to assess EMSs and consists of a long form (YSQ-L) and a short form (YSQ-S). The YSQ-S is made up of 90 items, representing the 18 EMSs defined by the authors, and it was created for 
research aims due to its faster administration than the long version (Young et al. 2003). In Young's (2003) theory, EMSs are organized into five domains: disconnection/rejection, impaired limits, overvigilance/inhibition, impaired autonomy/performance and other-directedness, but more recently Bach and colleagues (2018) have found a better fit in a model with four domains: disconnection \& rejection, impaired autonomy \& performance, excessive responsibility \& standards, and impaired limits.

Currently, the YSQ is in its third version (YSQ-S3) (Young, 2005), but to the best of our knowledge, this is the first study that aims to validate the Italian version of YSQ-S3 according to the new proposed organization of EMSs into four domains (Bach, Lockwood, \& Young, 2018).

Therefore, the purpose of this study is to examine the factor structure of the YSQ-S3 in a non-clinical Italian population by means of confirmatory factor analysis (CFA), and also to explore the internal consistency, test-retest reliability and concurrent validity of the YSQ-S3, using measures of depression and anxiety for concurrent validity assessment.

\section{Methods}

\section{Participants and procedure}

Students at the School of Medicine, Nursing Sciences and Sociology from the University "Magna Graecia" of Catanzaro (Italy), and seniors from 14 high schools from 6 different cities in Calabria (Southern Italy) were given the opportunity to participate to the study. The aim of the research was described on the Facebook page of the Ambulatory for Clinical Research and Treatment of Eating Disorders of Catanzaro (Italy). Through an anonymous online survey, the participants completed an informed consent form and the questionnaires. Anonymity was guaranteed using a nickname (formed by at least 8 alphanumeric and symbols characters) that participants used both in the first (test) and in the second administration (retest) of the tests.

The final sample consisted of 1372 participants $(\mathrm{N}=846$; $61.7 \%$ women) with mean age $19.45 \pm 2.7$ years old; 929 $(67.7 \%)$ participants had middle school diploma while 443 $(32.3 \%)$ had high school diploma. No differences were evident between males and females (respectively $19.3 \pm 2.8$ and $19.5 \pm 2.5 ; \mathrm{t}=1.592 ; \mathrm{p}=.112)$. All participants were Caucasian.

The retest was made available to participants three weeks later for a week; overall, $892(65 \%)$ participants completed a retest after $24.4 \pm 3.5$ days.

The research was conducted from March 2017 to May 2018.

\section{Instruments}

Young Schema Questionnaire S3 (YSQ-S3)

The authors made a double Italian/English forward/backward translation of the YSQ-S3 as follows: once an initial agreement was reached among translators from English to Italian, another researcher, blind to this original version, made the translation back into English. After verifying the similarity with the original test, the YSQ-S3 was given to a small group of 20 volunteers who evaluated the comprehensibility of the items. All raters considered it to be clear and easy to rate.

The YSQ-S3 is made up of 90 Likert type items ranging from 1 (completely untrue for me) to 6 (describes me perfectly) written to assess the presence of the 18 EMSs (Appendix 1).

\section{Beck Depressive Inventory (BDI)}

Depressive symptoms were measured using the Italian version of the BDI (Ghisi et al. 2006), which consists of 21 multiple-choice items, rated from 0 to 3 . Scores between 0 $9,10-16,17-29$ and $\geq 30$ respectively indicate minimum, mild, moderate and severe depression. Cronbach's alpha in the present research was .886 .

\section{State-Trait Anxiety Inventory (STAI)}

The Italian version is made up of 40 items and assesses state (STAI-St) and trait (STAI-Tr) anxiety (Pedrabissi and Santinello 1989). In this study, we examined only STAI-Tr and the Cronbach's alpha was .934.

\section{Data analyses}

Different CFAs were conducted using M-plus (Muthén and Muthén 1998-2015) to examine the best latent structure of the YSQ-S3, including both first- and second-order structures. Firstly, we examined a correlated first-order 18-factor structure, corresponding to the 18 hypothetical EMSs; secondly, we tested a second-order 5-factor structure corresponding to the five domains proposed by Young et al. (2003); finally, we tested a second-order 4-factor structure corresponding to the new organization of EMSs into four domains proposed by Bach et al. (2003).

The weighted least square mean and variance adjusted (WLSMV) method was used to estimate the parameters, because it provides the best option for modelling categorical or ordered data (Brown, 2006).

The Tucker-Lewis Index (TLI), The Comparative Fit Index (CFI), the Root Mean Square Error of Approximation (RMSEA), Standardized Root Mean Squared Residual (SRMR) and relative chi-square $\left(\chi^{2} / \mathrm{df}\right)$ were used to assess the goodness of fit of data to a proposed model. For TLI and CFI, values of 0.90 and above were considered adequate, 
whereas values of 0.95 or above were considered very good; for RMSEA values of 0.08 and below was considered adequate and 0.05 or less very good; for SRMR a cut-off value close to 0.08 was considered adequate. Values of $\chi^{2} / \mathrm{df}<3.0$ are good and those $<2.0$ are very good. The levels of these indices were evaluated according to the recommendations of $\mathrm{Hu}$ and Bentler (1999).

The McDonald's $\omega$ reliability coefficient was calculate using JASP open-source software (JASP, Version 0.9.2, University of Amsterdam, The Netherlands).

The intra-class correlation coefficient (ICC) along with the $95 \%$ confidence interval (CI) was run to calculate testretest reliability. According to Cicchetti's suggestions, we considered that ICC $<.40, .40-.59, .60-.74$, and $.75-1.00$ respectively indicate that the level of clinical significance was poor, fair, good and excellent (Cicchetti, 1994).
Correlations between YSQ-S3 and STAI-Tr and BDI were calculated to measure construct validity, considering that correlation coefficients greater than .30 are recommended (McGraw \& Wong, 1996).

A $p<.05$ was considered statistically significant.

\section{Results}

\section{Reliably of the scores}

As displayed in Table 1, the McDonald $\omega$ coefficient of the 18 EMSs ranged from .698 (Enmeshment) to .893 (Failure), indicating very good reliability.

Regarding test-retest reliability, ICC (95\% CI) ranged from .755 (.665-.819) for Entitlement to .943 (.930-.953) for Failure, showing an excellent stability.

Table 1. Descriptive statistics of the 18 EMSs of YSQ-S3 (N=1,372).

\begin{tabular}{|c|c|c|c|c|}
\hline & Mean & $(S D)$ & McDonald's $\omega$ & ICC 95\% CI \\
\hline Emotional deprivation & 1.8 & 1.0 & .843 & $.914(.895-.930)$ \\
\hline Abandonment & 2.4 & 1.2 & .833 & $.894(.872-.914)$ \\
\hline Mistrust/Abused & 2.5 & 1.2 & .850 & $.899(.870-.922)$ \\
\hline Social isolation & 2.2 & 1.2 & .855 & $.907(.884-.926)$ \\
\hline Defectiveness & 1.8 & 1.0 & .877 & $.905(.885-.923)$ \\
\hline Failure & 1.9 & 1.1 & .893 & $.943(.930-.953)$ \\
\hline Dependence & 1.7 & 0.8 & .760 & $.814(.774-.849)$ \\
\hline Vulnerability & 1.9 & 1.0 & .779 & $.891(.867-.911)$ \\
\hline Enmeshment & 1.8 & 0.8 & .698 & $.802(.749-.845)$ \\
\hline Subjugation & 1.8 & 0.9 & .764 & $.875(.849-.899)$ \\
\hline Self-sacrifice & 3.1 & 1.2 & .819 & $.819(.724-.876)$ \\
\hline Emotional inhibition & 2.5 & 1.2 & .815 & $.897(.875-.917)$ \\
\hline Unrelenting standards & 3.1 & 1.1 & .699 & $.799(.762-.856)$ \\
\hline Entitlement & 2.7 & 1.1 & .744 & $.755(.665-.819)$ \\
\hline Insufficient self-control & 2.3 & 1.0 & .769 & $.847(.814-.876)$ \\
\hline Approval-seeking & 2.4 & 1.1 & .819 & $.896(.869-.918)$ \\
\hline Negativism & 2.4 & 1.2 & .840 & $.890(.860-.914)$ \\
\hline Self-punitiveness & 2.4 & 1.0 & .784 & $.827(.771-.869)$ \\
\hline
\end{tabular}

\section{Confirmatory factor analysis}

The fit indices of the three CFA models tested are shown in Table 2. It is evident that some of the fit indices of these models do not meet the cutoff to define a model as valid (i.e. $\left.\chi^{2} / \mathrm{df}, \mathrm{CFI}, \mathrm{TLI}\right)$. However, the distributions of fit indices are affected by different conditions such as the sample size and the distribution of the data (Yuan, 2005). Therefore, cutoffs of fit indices cannot be considered the only way to evaluate a model's validity. For this reason, low fit indices do not necessarily indicate a poor fit. McNeish et al. (2018) sug- gested evaluating the validity of factor models not only on goodness of fit indices, but also with factor loadings that represent the quality of measurement of latent variables. In fact, according to the reliability paradox, it can be observed that models with low factor loadings could have better fit indices than model with high factor loadings (Hancock \& Mueller, 2011).

Based on these recommendations, the second-order model with four factors has the highest factor loadings when compared with the other two models (as displayed in figure 1).

Table 2. Fit indices of the tested models.

\begin{tabular}{|c|c|c|c|c|c|}
\hline & $\chi^{2} / \mathrm{df}$ & CFI & TLI & RMSEA $(90 \% \mathrm{CI})$ & SRMR \\
\hline Threshold for good models & $\leq 2$ & $\geq .95$ & $\geq .95$ & $\leq .05$ & $\leq .05$ \\
\hline Threshold for acceptable models & $\leq 3$ & $\geq .90$ & $\geq .90$ & $\leq .08$ & $\leq .08$ \\
\hline 18 correlated first-order factors (Young's schemas) & 5.028 & .790 & .776 & $.054(.053-.055)$ & .073 \\
\hline 5 correlated second-order factors (Young's revised theory, 2003) & 5.621 & .751 & .743 & $.058(.057-.059)$ & .076 \\
\hline 4 correlated second-order factors (Bach et al. 2018) & 5.556 & .754 & .746 & $.058(.057-.059)$ & .080 \\
\hline
\end{tabular}




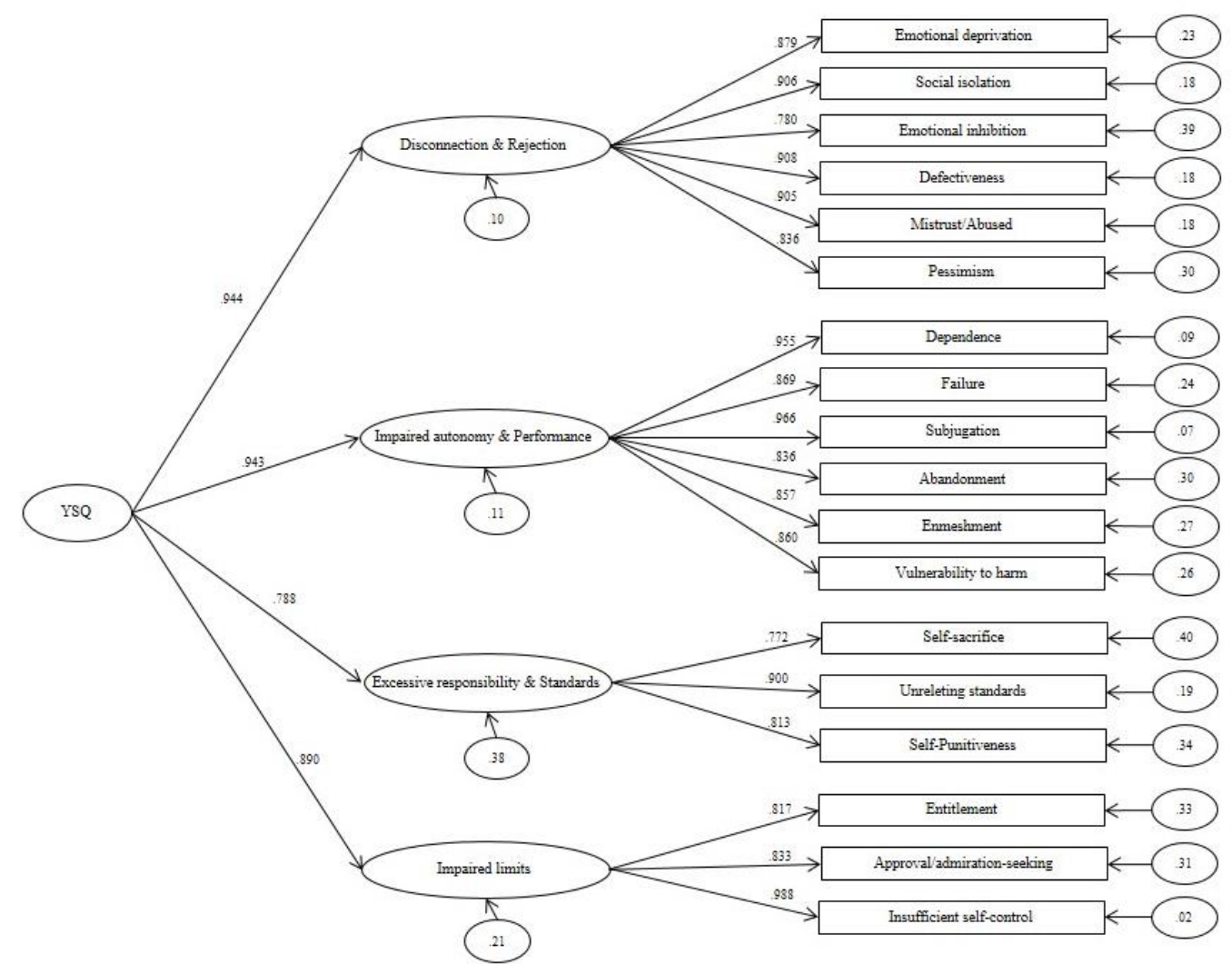

Figure 1. Caption. Path diagram of the second-order model of the YSQ-S3 (18 schemas and 4 domains) with reported standardized coefficients of first- and second-order loadings and residuals. Residuals are reported in circles. All values are significant for $\mathrm{p}<0.001$.

\section{Sources of validity evidence of internal structure}

As displayed in Table 3, all 18 EMSs were significantly correlated with the BDI (ranging from .143 for Unrelenting standards to .707 for Negativism) and STAI (ranging from .141 for Unrelenting standards to .768 for Negativism).

Table 3. Correlations between the 18 EMSs of the YSQ-S3 with BDI and STAI.

\begin{tabular}{|c|c|c|c|c|c|c|c|c|c|c|c|c|c|c|c|c|c|c|c|}
\hline & 1 & 2 & 3 & 4 & 5 & 6 & 7 & 8 & 9 & 10 & 11 & 12 & 13 & 14 & 15 & 16 & 17 & 18 & $19 \quad 20$ \\
\hline 1. BDI & - & & & & & & & & & & & & & & & & & & \\
\hline 2. STAI & $.809^{* *}$ & - & & & & & & & & & & & & & & & & & \\
\hline 3. Emotional deprivation & $.573^{* *}$ & $.559^{* *}$ & - & & & & & & & & & & & & & & & & \\
\hline 4. Abandonment & $.552^{* *}$ & $641^{* *}$. & $.583^{* *}$ & - & & & & & & & & & & & & & & & \\
\hline 5. Mistrust/Abused & $.593^{* *}$ & $622^{* *}$. & $.641^{* *}$ & $.717^{* *}$ & - & & & & & & & & & & & & & & \\
\hline 6. Social isolation & $.653^{* *}$ & $665^{* *}$. & $.691^{* *}$ & $.609^{* *}$ & $.710^{* *}$ & - & & & & & & & & & & & & & \\
\hline 7. Defectiveness & $.656^{* *}$ & $633^{* *}$. & $.734^{* *}$ & $.618^{* *}$ & $.646^{* *}$ & $.763^{* *}$ & - & & & & & & & & & & & & \\
\hline 8. Failure & $.650^{* *}$ & $.726^{* *}$. & $.602^{* *}$ & $.574^{* *}$ & $.531^{* *}$ & $.643^{* *}$ & $.715^{* *}$ & - & & & & & & & & & & & \\
\hline 9. Dependence & $.589^{* *}$ & $640^{* *}$. & $.555^{* *}$ & $.578^{* *}$ & $.494^{* *}$ & $.586^{* *}$. & $671^{* *}$. & $762^{* *}$ & - & & & & & & & & & & \\
\hline 10. Vulnerability & $.575^{* *}$ & $607^{* *}$. & $.529^{* *}$ & $.595^{* *}$ & $.589^{* *}$ & $.580^{* *}$. & $592 * *$ & $616^{* *}$. & $629^{* *}$ & - & & & & & & & & & \\
\hline 11. Enmeshment & $.434^{* *}$ & $466^{* *}$. & $.453^{* *}$ & $.498^{* *}$ & $.474^{* *}$ & $487^{* *}$. & $493^{* *}$. & $518^{* *}$. & $626^{* *}$ & $592^{* *}$ & - & & & & & & & & \\
\hline 12. Subjugation & $.635^{* *}$ & $658^{* *}$. & $.623^{* *}$ & $.644^{* *}$ & $.590^{* *}$ & $634^{* *}$. & $673^{* *}$ & $682^{* *}$ & $719^{* *}$. & $641^{* *}$ & $648^{* *}$ & - & & & & & & & \\
\hline 13. Self-sacrifice & $.373^{* *}$ & $370^{* *}$. & $.362^{* *}$ & $.549^{* *}$ & $.546^{* *}$ & $418^{* *}$. & $332^{* *}$. & $371^{* *}$ & $342^{* *}$. & $374^{* *}$. & $415^{* *} .4$ & $456^{* *}$ & - & & & & & & \\
\hline 14. Emotional inhibition & $.449^{* *}$ & $477^{* *}$. & $.572^{* *}$ & $.485^{* *}$ & $.618^{* *}$ & $666^{* *}$ & $607^{* *}$. & $507^{* *}$ & $461^{* *}$. & $495^{* *}$ & $418^{* *} .5$ & $542^{* *} .3$ & $389^{* *}$ & - & & & & & \\
\hline 15. Unrelenting standards & $.143^{*}$ & $.141^{*}$. & $.365^{* *}$ & $.457^{* *}$ & $.559^{* *}$ & $454^{* *}$. & $381^{* *}$. & $320^{* *}$ & $314^{* *}$ & $407^{* *}$. & $377^{* *} .3$ & $388^{* *} .5$ & $563^{* *} .5$ & $522^{* *}$ & - & & & & \\
\hline 16. Entitlement & $.261^{* *}$ & $283^{* *}$. & $.395^{* *}$ & $.462^{* *}$ & $.567^{* *}$ & $496^{* *}$. & $380^{* *}$. & $348^{* *} .3$ & $391^{* *} .4$ & $437^{* *}$ & $417^{* *} .4$ & $446^{* *} .4$ & $467^{* *} .4$ & $477^{* *} .6$ & $665^{* *}$ & - & & & \\
\hline 17. Insufficient self-contro & $1.530^{* *}$ & $610^{* *}$. & $.544^{* *}$ & $.579^{* *}$ & $.600^{* *}$ & $609^{* *}$. & $568^{* *}$. & $672^{* *}$ & $641^{* *} .5$ & $584^{* *}$. & $505^{* *}$ & $640^{* *} .4$ & $427^{* *} .5$ & $543^{* *} .4$ & $488^{* *}$ & $617^{* *}$ & - & & \\
\hline 18. Approval-seeking & $.362^{* *}$ & $468^{* *}$. & $.447^{* *}$ & $.548^{* *}$ & $.557^{* *}$ & $471^{* *}$. & $452^{* *}$. & $466^{* *}$ & $471^{* *} .5$ & $532^{* *}$. & $475^{* *} .5$ & $563^{* *} .4$ & $431^{* *} .4$ & $435^{* *} .5$ & $536^{* *}$. & $595^{* *}$ & $623^{* *}$ & & \\
\hline 19. Negativism & $.707^{* *}$ & $768^{* *}$. & $.589^{* *}$ & $.684^{* *}$ & $.715^{* *}$ & $611^{* *}$. & $616^{* *}$. & $615^{* *}$. & $575^{* *} .7$ & $751^{* *}$. & $504^{* *}$ & $606^{* *} .5$ & $507^{* *} .5$ & $548^{* *} .5$ & $540^{* *}$ & $509^{* *}$ & $635^{* *}$. & $605^{* *}$ & \\
\hline 20. Self-punitiveness & $.351^{* *}$ & $343^{* *}$. & $.486^{* *}$ & $.495^{* *}$ & $.530^{* *}$ & $.529^{* *}$. & $532^{* *}$. & $503^{* *}$ & $481^{* *} .4$ & $485^{* *}$. & $423^{* *} .5$ & $527^{* *} .4$ & $439^{* *} .4$ & $479^{* *} .5$ & $590^{* *}$. & $475^{* *}$ & $522^{* *}$. & $521^{* *} .6$ & $601^{* *}-$ \\
\hline
\end{tabular}




\section{Discussion}

The aim of the present research was to validate the new four-domain model of the YSQ-S3 in a large non-clinical sample. Recently, several studies have investigated the role of each EMS in the psychiatric disorders; for this reason, having a psychometrically valid assessment tool tested in a nonclinical sample is necessary and very useful.

Our results indicate that this version of the YSQ-S3 is a solid tool with good psychometric properties, in particular good reliability and excellent test-rest reliability. Furthermore, the McDonald's $\omega$ of almost all EMSs were higher than 0.7 , which indicated good internal reliability. However, Unrelenting Standards and Enmeshment had slightly less than good internal consistency, although they were still within the adequate range. The low reliability coefficients of these two EMSs were similar to previous versions in other languages (Calvete, Orue, \& González-Diez, 2013; Hawke \& Provencher, 2012; Soygüt, Karaosmanoğlu, \& Cakir, 2009), so it seems that our version of YSQ-S3 has good enough reliability to be used without serious revision.

Regarding the CFAs, previous validation studies of YSQS3 have tested the latent factor structure of the questionnaire and they found mixed results. In fact, some researchers have centered their interest on the first-order factors, namely the 18 EMSs (Hawke \& Provencher, 2012; Lee, Choi, Rim, Won, \& Lee, 2015), while others have gone further, describing some of the five second-order domains (Calvete et al. 2013; Kriston et al. 2012; Sakulsriprasert et al. 2016). These discrepancies in the factor structures may be for different reasons, such as translation problems, the sample used in the research or cultural differences.

In our study, although some model fit indices were not good, factor loadings appeared robust. In fact, even if the first-order factors model showed the best fit, some loadings of the 90 items did not appear to be significant for the corresponding EMS. Instead, in the second-order model, the factor loadings of all the four domains on their EMSs were significant. Therefore, this last model was chosen, as it showed more adequate measurement properties than the other two models.

Regarding concurrent validity, each schema of the YSQS3 was highly correlated with BDI and STAI-Tr scores, and this result is consistent with the versions of the YSQ-S3 in other languages (Lee et al. 2015; Soygut et al. 2009). This finding is not surprising; in fact, the EMSs are well known to be implicated in depressive and anxiety symptoms (Davoodi

\section{References}

Bach, B., Lockwood, G., \& Young, J. E. (2018). A new look at the schema therapy model: organization and role of early maladaptive schemas. Cognitive Behaviour Therapy, 47(4), 328-349. https://doi.org/10.1080/16506073.2017.1410566

Basile, B., Tenore, K., Luppino, O. I., Mancini, F., \& Basile, B. (2017). Schema therapy mode moldel applied to OCD. Clinical Neuropsychiatry, 14(6), 407-414. et al. 2018; Rezaei et al. 2016). For this reason, some researchers have proposed that ST should be also applied in the treatment of mood and anxiety disorders (Hawke \& Provencher, 2011; Malogiannis et al., 2014).

Our results should be interpreted with caution due to certain limitations. First, in the present study, all data were obtained via online questionnaires. On one hand, this allows for recruitment of a large number of participants, but on the other hand it could lead to a selection or response bias (Mayr et al., 2012). Second, our sample is composed of a large non clinical population, so caution is needed in generalizing our findings. There are various reasons why we feel our choice was justified. First, the validation of a test in a foreign language has the aim to demonstrate that the new version matches with the original one, whose validity has been already demonstrated by the authors of the test. In addition, many studies regarding YSQ-S3 validations in other languages have used sample with student populations (Calvete et al. 2013; Lee et al. 2015; Sakulsriprasert et al. 2016). Nevertheless, we believe that further studies with a clinical sample of Italian patients are necessary to replicate and extend the present results. Finally, our study being based on selfreport questionnaires could be subject to some limits as reduced introspective ability of respondents, social desirable answers, response bias or sampling bias. However, selfreport scales allow a 'cheap' way in terms of both time and cost of obtaining data; furthermore, they can be used to measure constructs that would be difficult to obtain with behavioral or physiological measures.

Despite these limitations, the strength of our research is that this is the first study that tests the new four-domain model recently proposed by the authors (Bach et al. 2018), which has received little attention to date.

\section{Conclusions}

Summing up, the Italian version of the YSQ-S3 has demonstrated sound psychometric properties such as good internal consistency and excellent test-retest reliability. In addition, the present study supports the new proposed organization of EMSs into four domains. Thus, this study has shown that the Italian version of YSQ-S3 can be a useful and valid tool for clinicians and researchers in the self-report measurement of EMSs.

Acknowledgments.- The authors are grateful to all partakers who accepted to participate in this research.

Brown, T. (2006). Confirmatory factor analysis for applied research. New York: Guildford.

Calvete, E., Orue, I., \& González-Diez, Z. (2013). An Examination of the Structure and Stability of Early Maladaptive Schemas by Means of the Young Schema Questionnaire-3. European Journal of Psychological Assessment, 29(4), 283-290. https://doi.org/10.1027/1015$5759 / \mathrm{a} 000158$ 
Calvete, E., Orue, I., \& Hankin, B. L. (2013). Early maladaptive schemas and social anxiety in adolescents: The mediating role of anxious automatic thoughts. Journal of Anxiety Disorders, 27(3), 278-288. https://doi.org/10.1016/j.janxdis.2013.02.011

Cicchetti, D. V. (1994). Guidelines, criteria, and rules of thumb for evaluating normed and standardized assessment instruments in psychology. Psychological Assessment, 6(4), 284-290. https://doi.org/10.1037/1040-3590.6.4.284

Davoodi, E., Wen, A., Dobson, K. S., Noorbala, A. A., Mohammadi, A., \& Farahmand, Z. (2018). Early maladaptive schemas in depression and somatization disorder. Journal of Affective Disorders, 235, 82-89. https://doi.org/10.1016/j.jad.2018.04.017

Ghisi, M., Flebus, G. B., Montano, A., Sanavio, E., \& Sica, C. (2006). Beck. Depression Inventory-II. Manuale italiano. Firenze: Organizzazioni Speciali.

Hancock, G. R., \& Mueller, R. O. (2011). The Reliability Paradox in Assessing Structural Relations Within Covariance Structure Models. Educational and Psychological Measurement, 71(2), 306-324. https://doi.org/10.1177/0013164410384856

Hawke, L. D., \& Provencher, M. D. (2011). Schema Theory and Schema Therapy in Mood and Anxiety Disorders: A Review. Journal of Cognitive Psychotherapy, 25(4), 257-276. https://doi.org/10.1891/08898391.25.4.257

Hawke, L. D., \& Provencher, M. D. (2012). The Canadian French Young Schema Questionnaire: Confirmatory factor analysis and validation in clinical and nonclinical samples. Canadian Journal of Behavioural Science/Revue Canadienne Des Sciences Du Comportement, 44(1), 40-49. https://doi.org/10.1037/a0026197

Hawke, L. D., Provencher, M. D., \& Arntz, A. (2011). Early Maladaptive Schemas in the risk for bipolar spectrum disorders. Journal of Affective Disorders, 133(3), 428-436. https://doi.org/10.1016/j.jad.2011.04.040

Kriston, L., Schäfer, J., von Wolff, A., Härter, M., \& Hölzel, L. P. (2012). The Latent Factor Structure of Young's Early Maladaptive Schemas: Are Schemas Organized Into Domains? Journal of Clinical Psychology, 68(6), 684-698. https://doi.org/10.1002/jclp.21846

Lee, S. J., Choi, Y. H., Rim, H. D., Won, S. H., \& Lee, D.-W. (2015). Reliability and Validity of the Korean Young Schema QuestionnaireShort Form-3 in Medical Students. Psychiatry Investigation, 12(3), 295. https://doi.org/10.4306/pi.2015.12.3.295

Malogiannis, I. A., Arntz, A., Spyropoulou, A., Tsartsara, E., Aggeli, A., Karveli, S., ... Zervas, I. (2014). Schema therapy for patients with chronic depression: A single case series study. Journal of Behavior Therapy and Experimental Psychiatry, 45(3), 319-329. https://doi.org/10.1016/j.jbtep.2014.02.003

Mayr, A., Gefeller, O., Prokosch, H. U., Pirkl, A., Fröhlich, A., \& De Zwaan, M. (2012). Web-based data collection yielded an additional response bias - But had no direct effect on outcome scales. Journal of Clinical Epidemiology, $\quad 65(9), \quad 970-977$. https://doi.org/10.1016/j.jclinepi.2012.03.005

McGraw, K. O., \& Wong, S. P. (1996). Forming inferences about some intraclass correlation coefficients. Psychological Methods, 1(1), 30-46. https://doi.org/10.1037/1082-989X.1.1.30

McNeish, D., An, J., \& Hancock, G. R. (2018). The Thorny Relation Between Measurement Quality and Fit Index Cutoffs in Latent Variable Models. Journal of Personality Assessment, 100(1), 43-52. https://doi.org/10.1080/00223891.2017.1281286

Muthén, L. K., \& Muthén, B. O. (1998-2015). Mplus User's Guide. Seventh Edition. Los Angeles, CA: Muthén \& Muthén.

Nunnally, J. (1978). Psychometric theory. 2nd ed. New York: McGraw-Hill.

Pedrabissi, L., \& Santinello, M. (1989). Inventario per l'Ansia di 'Stato' e di 'Tratto': Nuova Versione Italiana dello STAI —Forma Y: Manuale. Firenze: Organizzazioni Speciali.

Pinto-Gouveia, J., Castilho, P., Galhardo, A., \& Cunha, M. (2006). Early Maladaptive Schemas and Social Phobia. Cognitive Therapy and Research, 30(5), 571-584. https://doi.org/10.1007/s10608-006-9027-8

Pugh, M. (2015). A narrative review of schemas and schema therapy outcomes in the eating disorders. Clinical Psychology Review, 39, 30-41. https://doi.org/10.1016/j.cpr.2015.04.003

Rezaei, M., Ghazanfari, F., \& Rezaee, F. (2016). The role of childhood trauma, early maladaptive schemas, emotional schemas and experimental avoidance on depression: A structural equation modeling.

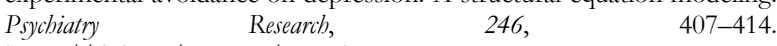
https://doi.org/10.1016/j.psychres.2016.10.037

Sakulsriprasert, C., Phukao, D., Kanjanawong, S., \& Meemon, N. (2016). The reliability and factor structure of Thai Young Schema Questionnaire-Short Form 3. Asian Journal of Psychiatry, 24, 85-90. https://doi.org/10.1016/j.ajp.2016.09.011

Sempértegui, G. A., Karreman, A., Arntz, A., \& Bekker, M. H. J. (2013). Schema therapy for borderline personality disorder: A comprehensive review of its empirical foundations, effectiveness and implementation possibilities. Clinical Psychology Review, 33(3), 426-447. https://doi.org/10.1016/j.cpr.2012.11.006

Shorey, R. C., Anderson, S., \& Stuart, G. L. (2013). Early Maladaptive Schemas of Substance Abusers and Their Intimate Partners. Journal of Psychoactive Drugs, 45(3), 266-275. https://doi.org/10.1080/02791072.2013.805982

Soygüt, G., Karaosmanoğlu, A., \& Cakir, Z. (2009). [Assessment of early maladaptive schemas: a psychometric study of the Turkish young schema questionnaire-short form-3]. Turk Psikiyatri Dergisi $=$ Turkish Journal of Psychiatry, 20(1), 75-84. Retrieved from http://www.ncbi.nlm.nih.gov/pubmed/19306129

Stowkowy, J., Liu, L., Cadenhead, K. S., Cannon, T. D., Cornblatt, B. A., McGlashan, T. H., ... Addington, J. (2016). Core Schemas in Youth at Clinical High Risk for Psychosis. Behavioural and Cognitive Psychotherapy, 44(02), 203-213. https://doi.org/10.1017/S1352465815000144

Voderholzer, U., Schwartz, C., Thiel, N., Kuelz, A. K., Hartmann, A., Scheidt, C. E., ... Zeeck, A. (2014). A Comparison of Schemas, Schema Modes and Childhood Traumas in Obsessive-Compulsive Disorder, Chronic Pain Disorder and Eating Disorders. Psychopathology, 47(1), 24 31. https://doi.org/10.1159/000348484

Young, J. E. (2005). Young schema questionnaire - Short form 3 (YSQ-S3). New York, NY: Cognitive Therapy Center.

Young, J.E., \& Brown, G. (1990). Young Schema Questionnaire. Cognitive Therapy Center of New York, New York, NY.

Young, J. E., Klosko, J. S., \& Weishaar, M. E. (2003). Schema therapy: A practitioner's guide. New York, NY: The Guilford Press.

Yuan, K.-H. (2005). Fit Indices Versus Test Statistics. Multivariate Behavioral Research, 40(1), https://doi.org/10.1207/s15327906mbr4001_5
115-148. 


\section{Appendix 1. Italian version of YSQ-S3 - 90 item}

\section{Istruzioni}

Di seguito è presentata una serie di affermazioni con cui è possibile descrivere se stessi. Per ogni singola affermazione indichi quanto accuratamente la descrive durante gli ultimi anni. Quando non si sente sicura/o, basi la sua risposta su cosa sente a livello emotivo e non su ciò che pensa possa essere giusto o sbagliato in generale. Alcune affermazioni si riferiscono alla relazione con i suoi genitori o con un eventuale partner. Se una (o più) di queste figure è deceduta, per favore risponda considerando la vostra relazione quando erano in vita. Se attualmente non ha un partner, ma ne ha avuti in passato, per favore risponda considerando la relazione significativa più recente.

1 = Completamente falso; 2 = Quasi del tutto falso; $3=$ Un po’ più vero che falso; $4=$ Abbastanza vero; $5=$ Quasi del tutto vero per me; $6=$ Mi descrive perfettamente

\begin{tabular}{|c|c|}
\hline $\begin{array}{l}\text { 1. Non ho avuto qualcuno che si prendesse cura di me, che mi rendesse partecipe della propria vita o avesse veramente a } \\
\text { cuore tutto ciò che mi accade }\end{array}$ & 123456 \\
\hline 2. Mi reputo "appiccicoso/a" nei confronti di coloro a cui tengo perché temo che possano abbandonarmi & 123456 \\
\hline 3. Sento che gli altri approfitteranno di me & 123456 \\
\hline 4. Non mi sento socialmente adeguato & 123456 \\
\hline 5. Nessun uomo/donna che desidero potrebbe amarmi dopo aver visto i miei difetti o le mie debolezze & 123456 \\
\hline 6. Quasi nulla di quello che faccio al lavoro (o nello studio) va bene quanto ciò che sanno fare gli altri & 123456 \\
\hline 7. Non mi sento in grado di cavarmela da solo/a nella vita di tutti i giorni & 123456 \\
\hline 8. Non riesco a liberarmi dalla sensazione che qualcosa di brutto stia per accadere & 123456 \\
\hline 9. Non sono riuscito a separarmi dai miei genitori come sembrano fare le altre persone della mia età & 123456 \\
\hline 10. Penso che se facessi quello che voglio mi metterei solo nei guai & 123456 \\
\hline 11. Sono quello che solitamente finisce con il prendersi cura delle persone care & 123456 \\
\hline $\begin{array}{l}\text { 12. Sono troppo controllato per mostrare agli altri i miei sentimenti positivi verso di loro (es. l'affetto che provo, il far vede- } \\
\text { re che ci tengo) }\end{array}$ & 123456 \\
\hline 13. Devo essere il/la migliore nella maggior parte delle cose che faccio; non accetto di essere secondo/a a nessuno & 123456 \\
\hline 14. Ho molti problemi ad accettare un "no" come risposta quando voglio qualcosa dagli altri & 123456 \\
\hline 15. Sembra che non riesca ad impormi la disciplina necessaria per portare a termine compiti routinari e noiosi & 123456 \\
\hline 16. Avere soldi e conoscere persone importanti mi fa sentire di valore & 123456 \\
\hline 17. Anche quando le cose sembrano andare bene, sento che sarà solo per poco & 123456 \\
\hline 18. Se commetto un errore, merito di essere punito & 123456 \\
\hline 19.Non ho nessuno che mi dia calore, sostegno e affetto & 123456 \\
\hline 20. Ho talmente bisogno degli altri da temere di perderli & 123456 \\
\hline 21. Sento di non poter abbassare la guardia in presenza degli altri, perché altrimenti mi ferirebbero intenzionalmente & 123456 \\
\hline 22. Sono radicalmente diverso/a dagli altri & 123456 \\
\hline 23. Nessun uomo/donna che desidero vorrebbe starmi vicino, se mi conoscesse realmente & 123456 \\
\hline 24. Sono incapace nel raggiungimento degli obiettivi & 123456 \\
\hline 25. Mi ritengo una persona dipendente dagli altri per quanto riguarda lo svolgimento delle attività quotidiane & 123456 \\
\hline 26. Sento che, in qualunque momento potrebbe colpirmi un disastro (naturale, criminale, finanziario o medico) & 123456 \\
\hline 27. Io e i miei genitori tendiamo ad essere troppo coinvolti nelle vite e nei problemi reciproci & 123456 \\
\hline $\begin{array}{l}\text { 28. Sento di non avere altra scelta se non cedere alle richieste degli altri, altrimenti essi si vendicheranno, arrabbieranno o mi } \\
\text { respingeranno in qualche modo }\end{array}$ & 123456 \\
\hline 29. Sono una brava persona perché penso agli altri più che a me stesso/a & 123456 \\
\hline 30. Trovo imbarazzante esprimere i miei sentimenti agli altri & 123456 \\
\hline 31. Cerco sempre di fare del mio meglio, non mi accontento di fare abbastanza & 123456 \\
\hline 32. Sono speciale e non dovrei accettare molti dei divieti o delle restrizioni imposte dagli altri & 123456 \\
\hline 33. Se non riesco a raggiungere un obiettivo, divento facilmente frustrato/a e $n$ & 123456 \\
\hline 34. Il raggiungimento di un risultato assume maggior valore per me se gli altri lo notano & 123456 \\
\hline 35. Se qualcosa di bello accade, mi preoccupo perché è probabile che sia seguito da qualcosa di brutto & 123456 \\
\hline 36. Se non faccio del mio meglio, devo aspettarmi di fallire & 123456 \\
\hline 37. Non ho sentito di essere speciale per nessuno & 123456 \\
\hline 38. Temo che le persone a me care possano lasciarmi o abbandonarmi & 123456 \\
\hline 39. È soltanto una questione di tempo ma prima o poi tutti mi tradiscono & 123456 \\
\hline 40. Non ho un senso di appartenenza, sono un solitario/a & 123456 \\
\hline 41. Non merito l'amore, l'attenzione e il rispetto degli altri & 123456 \\
\hline 42. La maggior parte delle persone è più competente di me nella sfera lavorativa e nel raggiungere le proprie mete & 123456 \\
\hline 43. Mi manca il buon senso & 123456 \\
\hline
\end{tabular}


44. Mi preoccupo del fatto di poter essere aggredito fisicamente

123456

45. È molto difficile, fra me e i miei genitori, mantenere il riservo sui dettagli intimi della nostra vita senza sentirci traditi o

123456 in colpa

46. Nelle relazioni, solitamente permetto alle altre persone di avere la meglio

47. Sono cosi impegnato ad occuparmi delle persone a cui tengo, da avere poco tempo per me stesso/a

123456

48. Trovo difficile essere uno spirito libero e spontaneo/a quando ho attorno altre persone

49. Devo assumermi tutte le mie responsabilità

50. Odio essere limitato/a o bloccato nel fare ciò che voglio

51. Faccio molta fatica a sacrificare il piacere o la gratificazione immediati per raggiungere un obiettivo a lungo termine

52. A meno che non riceva molte attenzioni da parte degli altri, non mi sento importante

53. Per quanto prudenti si possa essere, c'è sempre qualcosa che andrà male

54. Se non faccio bene qualcosa, ne devo pagare le conseguenze

55. Nessuno mi ha mai realmente ascoltato, capito, o è stato in sintonia con i miei reali bisogni ed emozioni

56. Quando qualcuno a cui tengo si allontana o si distacca da me, mi sento disperato

57. Sono abbastanza sospettoso/a sulle reali intenzioni degli altri

58. Mi sento alienato/a o escluso/a dagli altri

59. Sento di non essere amabile

60. Non ho il talento di cui è dotata la maggior parte delle persone sul lavoro

61. Nella vita di tutti i giorni, non si può fare affidamento sul mio parere

62. Ho paura di perdere tutti i soldi e finire in rovina

63. Spesso mi sento come se i miei genitori si appoggiassero a me ed io non avessi una vita mia

64. Ho sempre permesso agli altri di fare le scelte al posto mio, perciò non so veramente cosa voglio per me stesso/a

65. Sono sempre stato/a quello/a che ascolta i problemi degli altri

66. Sono talmente controllato che molte persone mi reputano freddo e insensibile

67. Sento una costante pressione a portare a termine a miei obiettivi e a non lasciare nulla in sospeso

68. Sento che non dovrei sottostare alle normali regole e convenzioni come invece fanno gli altri

69. Non riesco ad costringermi a fare ciò che non mi piace, anche quando so che è per il mio stesso bene

123456

123456

123456

123456

123456

123456

123456

123456

123456

123456

123456

123456

123456

123456

123456

123456

123456

123456

123456

123456

123456

123456

123456

70. Se intervengo ad un incontro o sono introdotto in una situazione sociale, è importante per me ottenere riconoscimento 123456 ed ammirazione

71. Indipendentemente dai miei sforzi sul lavoro, mi preoccupo di poter essere rovinato finanziariamente e di perdere quasi 123456 tutto ciò che possiedo

72. Indipendentemente dalla ragione per cui ho sbagliato, una volta commesso un errore, dovrei pagarne le conseguenze

73. Nei momenti di incertezza, non ho avuto accanto una persona forte o di buon senso per darmi delle indicazioni o dei consigli utili

74. Qualche volta sono così preoccupato/a di essere lasciato/a da qualcuno che lo allontano io stesso/a

75. Spesso mi interrogo e rifletto per cercare di scoprire le motivazioni nascoste e i secondi fini delle altre persone

76. Mi sento sempre al di fuori dei gruppi

77. Sono troppo inaccettabile per rivelarmi agli altri o per permettere che mi conoscano a fondo

78. Nel lavoro e nello studio, non sono intelligente quanto la maggior parte delle persone

79. Non mi sento sicuro/a della mia capacità di risolvere i problemi di tutti i giorni

80. Temo di stare sviluppando una malattia grave anche se non mi è stato diagnosticato nulla del genere da nessun medico

81. Spesso sento di non avere un'identità separata da quella dei miei genitori o del mio partner

82. Ho molti problemi a chiedere che i miei diritti vengano rispettati e le mie emozioni siano prese in considerazione

83. Le altre persone mi vedono come qualcuno che fa troppo per gli altri e non abbastanza per se stesso/a

84. Nella sfera emotiva, le persone mi giudicano rigido

85. Non riesco facilmente a tirarmi fuori dai guai o a trovare scuse per i miei errori

86. Sento che quello che ho da offrire io è di maggior valore rispetto al contributo degli altri

87. Raramente sono stato capace di mantenere una condotta coerente con le mie decisioni

88. Ricevere molti elogi e complimenti mi fa sentire una persona di valore

89. Mi preoccupa il fatto che una decisione sbagliata possa portare ad un disastro 